\title{
EHMTI-0329. Cluster headaches - experience from a tertiary children's headache clinic
}

\author{
P Prabhakar", A Gerth, C Toolis, P Goadsby \\ From 4th European Headache and Migraine Trust International Congress: EHMTIC 2014 \\ Copenhagen, Denmark. 18-21 September 2014
}

\section{Introduction}

Tension Type Headache (TTH 39\%) and Migraine (with and without aura 33\%) are the most common primary headache seen in paediatric headache clinics. Rare headaches including Cluster Headaches $(\mathrm{CH})$ account for 8\% (Abu Arafeh 2013).

\section{Aims}

To study the prevalence and clinical characteristics of children with $\mathrm{CH}$.

\section{Methods}

A retrospective case-note study from January 2006 December 2013 was undertaken.

\section{Results}

Of the 472 new referrals 9 had $\mathrm{CH}(1.9 \%)$. Mean age at presentation was 10 years 11 months (6y5m to $16 y 10 \mathrm{~m}$ ). Two had chronic $\mathrm{CH}$ and seven episodic $\mathrm{CH}$. 3/9 had multiple headache types (cluster + migraine.) One had a family history of $\mathrm{CH}$.

All headaches were described as severe or very severe and descriptive terms ranged from sharp to stabbing to throbbing to pounding. Location was always unilateral with neither side dominating. 7 experienced autonomic symptoms with no particular one standing out. All were agitated. 7 had some degree of photo or phonophobia. None were affected by movement.

All had normal neuroimaging (usually MRI) except one (cerebellar-pontine angle dermoid). Three had normal pituitary tests. Examination elicited occipital nerve tenderness in 7 but was otherwise normal. Mean time to diagnosis was 25 months (range 4-91). No treatment was consistently effective. Inranasal sumatriptan and occipital nerve injection were effective in three cases each.

\section{Conclusions}

Cluster headaches can evolve over time in children. Agitation is a key feature of the condition.

No conflict of interest.

Published: 18 September 2014

doi:10.1186/1129-2377-15-S1-B26

Cite this article as: Prabhakar et al:: EHMTI-0329. Cluster headaches -

experience from a tertiary children's headache clinic. The Journal of

Headache and Pain 2014 15(Suppl 1):B26.

Submit your manuscript to a SpringerOpen ${ }^{\odot}$ journal and benefit from:

- Convenient online submission

- Rigorous peer review

- Immediate publication on acceptance

- Open access: articles freely available online

- High visibility within the field

- Retaining the copyright to your article

Submit your next manuscript at $\boldsymbol{~ s p r i n g e r o p e n . c o m ~}$

Neurology, Great Ormond Street Hospital, London, UK 